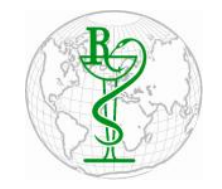

INDO GLOBAL JOURNAL OF

PHARMACEUTICAL SCIENCES

ISSN 2249- 1023

\title{
Comparison of Analgesic Effect of Intravenous Magnesium Sulphate \& Ketorolac in Management of Acute Pain in Upper Limb Orthopaedic Trauma
}

\author{
Rajmala Jaiswal, Teena Bansal *, Navdeep Kaur, Geeta Ahlawat \\ Department of Anaesthsiology \& Critical Care, Pt. B.D. Sharma University of Health Sciences, Rohtak-124001, Haryana, India
}

\begin{abstract}
Address for
Correspondance

Teena Bansal, aggarwalteenu@r ediffmail.com

ABSTRACT: The present study was undertaken to compare the analgesic effect of magnesium with ketorolac in acute orthopaedic trauma of upper limb. A total of 60 patients having physical status grade I or II of either sex belonging to age group of 20-60 years presenting with acute closed fracture in one upper limb were included in the study. The patients were randomly allocated to one of the two groups. Group $M(n=30)-$ received $2 \mathrm{~g}$ of magnesium sulphate diluted in $100 \mathrm{ml}$ NS slowly over 15 minutes intravenously every 8 hours

Keywords for 24 hours. Group K ( $\mathrm{n}=30$ )- received $30 \mathrm{mg}$ of Ketorolac diluted in $100 \mathrm{ml}$ NS slowly over 15 minutes

Magnesium intravenously every 8 hours for 24 hours. The mean consumption of fentanyl (rescue analgesia) in $\mathrm{M}$ group was $168.93 \pm 24.64,152.67 \pm 29.15,122.33 \pm 34.23 \mu \mathrm{g}$ while it was nil in $\mathrm{K}$ group at $0-8 \mathrm{hrs}, 8-16 \mathrm{hrs}, 16-24$

Sulphate;

Ketorolac;

Fentanyl; Upper hrs respectively. The mean difference in consumption of fentanyl within $\mathrm{M}$ group between $0-8 \mathrm{hrs}$ and 8-16 hrs was $16.267 \mu \mathrm{g}$ (p value $=0.003), 8-16 \mathrm{hrs}$ and $16-24 \mathrm{hrs}$ was $30.33 \mu \mathrm{g}(\mathrm{p}$ value $=0.000)$ and $0-8 \mathrm{hrs}$ and 16$24 \mathrm{hrs}$ was $46.600 \mu \mathrm{g}$ (p value $=0.000$ ), statistically significant. Ketorolac proved to be a better analgesic compared to magnesium. () 2015 iGlobal Research and Publishing Foundation. All rights reserved.

Limb
\end{abstract}

Orthopaedic Trauma.

\section{INTRODUCTION}

There have been many advances in the management of acute pain through different modalities like peripheral nerve blocks and drugs. Drugs remain the mainstay of effective acute pain relief. In patients with fractures pain relief is of utmost importane. Various drugs which are mainly used include NSAIDs, opioids and local anaesthetics. Recently the importance of magnesium, an $\mathrm{N}$-methyl D-aspartate receptor antagonist in anaesthetic practice has been highlighted as analgesic.

Ketorolac, a NSAID is widely used as an analgesic agent. It inhibits prostaglandin synthesis and relieves pain by peripheral mechanism [1]. Unlike opioids tolerance, withdrawl and respiratory depression do not occur with ketorolac. It is one of the few NSAIDS approved for parenteral administration [2].
Magnesium has the potential to treat and prevent pain by acting as an antagonist of N-methyl-D-aspartate (NMDA) receptors [3]. Clinical studies suggest that magnesium sulphate possesses analgesic property and has shown to improve quality of pain management in perioperative period. It has often been used as an adjuvant, however none of the studies have been done so far where magnesium sulphate has been used as a primary drug for the management of acute traumatic pain.

The present study evaluates the analgesic effect of magnesium in acute orthopaedic trauma of upper limb and compares its analgesic efficacy with ketorolac, a commonly used NSAID. 


\section{Indo Global Journal of Pharmaceutical Sciences, 2015; 5(3): 199-204}

\section{MATERIALS \& METHODS}

This prospective, double blind randomized study was conducted in the Department of Anaesthesiology and Critical Care, Pt. B. D. Sharma UHS, Rohtak after obtaining approval from the institutional research/ethical committee. A total of 60 patients having physical status grade I or II according to American Society of Anesthesiologists (ASA) of either sex belonging to age group of 20-60 years, presenting with acute closed fracture in one upper limb were included in the study.

Patients having body mass index > 35kg/m2, open wounds, head injury, multi-organ injury, opioids/NSAIDs abuse or on chronic treatment, prior treatment with calcium channel blockers or having cardiovascular, hepatic and renal diseases were excluded from the study.

After arrival of patient in Accident and Emergency room, patients were subjected to a detailed clinical history and a general physical as well as systemic examination and all patients received inj. diclofenac $75 \mathrm{mg}$ IM on admission. The patients underwent radiological examination for evaluation of the fracture. The patient who had acute closed fracture on X-ray and who could be operated after 24 hours were included in the study. The purpose and protocol of the study including severity of pain as per visual analogue scale (VAS) $(0=$ no pain to $10=$ worst pain) were explained to the patient. Informed written consent was obtained from the patients. Routine investigations like haemoglobin ( $\mathrm{Hb})$, bleeding time (BT), clotting time (CT), complete urine examination, serum $\mathrm{Mg} 2+$ initially and after $24 \mathrm{hrs}$, ECG and any other relevant investigation, if needed was carried out and recorded.

The patients were randomly assigned to two groups of 30 each using sealed envelope method (containing assigned group).

Group M (n=30)- received dose of $2 \mathrm{~g}$ of magnesium sulphate diluted in $100 \mathrm{ml}$ NS slowly over 15 minutes intravenously every 8 hours for 24 hours.

Group K (n=30)- received dose of 30mg of ketorolac diluted in $100 \mathrm{ml}$ NS slowly over 15 minutes intravenously every 8 hours for 24 hours.

All patients were monitored for continuous ECG, oxygen saturation $(\mathrm{SpO} 2)$ and non-invasive blood pressure. After the intravenous line was established patients received either IV doses of magnesium or ketorolac as per group allocation. After 30 minutes from the start of infusion, pain score was re-assessed. If VAS was $>2$, then rescue analgesia was given in the form of fentanyl through a patient controlled analgesia (PCA) pump.4 The PCA pump was set to deliver $25 \mu \mathrm{g}$ bolus of fentanyl with a 10 minute lockout interval. Hypotension defined as decrease in systolic blood pressure by more than $20 \%$ from baeline or less than $90 \mathrm{~mm} \mathrm{Hg}$ was treated with inj. ephedrine $3 \mathrm{mg}$ IV. Bradycardia defined as heart rate less than 50 bpm was treated with inj. atropine $0.6 \mathrm{mg}$ IV. Desaturation defined as oxygen saturation of less than $90 \%$ was treated by oxygen inhalation via facemask. In case of any other adverse effects, drug was stopped immediately and subsequent dose was withheld. Patients were observed for 24 hours and following parameters were recorded.

1.Consumption of rescue analgesia (fentaynl) in $24 \mathrm{hrs}$

2. Sedation was assessed by Ramsay Sedation Scale every $2 \mathrm{hrs}$ for $24 \mathrm{hrs} 5$

3 .Serum $\mathrm{Mg} 2+$ before and after $24 \mathrm{hrs}$

4 Deep tendon reflexes were assessed in lower limbs every $2 \mathrm{hrs}$ for $24 \mathrm{hrs}$

5.Pulse rate (PR), blood pressue (BP),Respiratory rate $(\mathrm{RR})$ and oxygen saturation $(\mathrm{SpO} 2)$ were recorded every $15 \mathrm{~min}$ for the $1 \mathrm{st} \mathrm{hr}$ after giving the dose and then every 2 hrs.

6. ECG changes like tachycardia, bradycardia, arrhythmias, widening of QRS complexes, prolongation of PR interval, and T-wave changes.

7.Total number of boluses of ephedrine and atropine in 24 hrs.

8. Side effects like nausea, vomiting, dizziness or pruritus were noted in both the groups.

\section{Statistical Analysis}

Collected data was entered in the MS Excel spreadsheet, coded appropriately and later cleaned for any possible errors. Analysis was carried out using SPSS (Statistical Package for Social Studies) for Windows version 20.0 and online Graph Pad software (Prism 5 for Windows) version 5.01. Clear values for various outcomes were determined before running frequency tests.

Pearson's chi-square test was used to evaluate differences between groups for categorized variables. Paired \& 


\section{Indo Global Journal of Pharmaceutical Sciences, 2015; 5(3): 199-204}

unpaired " $\mathrm{t}$ " test was used to calculate difference of means for quantitative variables.

Normally distributed data were presented as means and standard deviation, or $95 \%$ confidence intervals (CI) . All tests were performed at a 5\% level of significance, thus an association was significant if the $p$ value was less than 0.05 .

\section{RESULTS \& DISCUSSION}

Patients belonging to group $M$ had a mean age of $29.57 \pm$ 8.48 years and patients in group $\mathrm{K}$ had a mean age of $40.57 \pm 13.60$ years. The mean weight of patients in group $\mathrm{M}$ and group $\mathrm{K}$ were $69.17 \pm 9.01 \mathrm{~kg}$ and $69.07 \pm$ $7.14 \mathrm{~kg}$ respectively. On applying the unpaired t-test, age and weight of patients in both the groups were comparable ( $p$ value $\geq 0.05$ ). In group $M$ male: female ratio was $3: 1$ and in group $\mathrm{K}$ it was $5: 1$. Using chi-square test, sex distribution in both the groups was comparable ( $p$ $\geq 0.05)$.

The mean consumption of rescue analgesia between group $\mathrm{M}$ and $\mathrm{K}$ at $0-8 \mathrm{hrs}$ was $168.93 \pm 24.64 \mu \mathrm{g}$ and 0.00 $\pm 0.00 \mu \mathrm{g}(\mathrm{p}$ value $=0.000)$, at $8-16 \mathrm{hrs}$ was $152.67 \pm$ $29.15 \mu \mathrm{g}$ and $0.00 \pm 0.00 \mu \mathrm{g}$ ( $\mathrm{p}$ value $=0.000)$; and at 16 $24 \mathrm{hrs}$ was $122.33 \pm 34.23 \mu \mathrm{g}$ and $0.00 \pm 0.00 \mu \mathrm{g}$ (p value $=0.000$ ) respectively. On applying paired t-test, the total consumption of rescue analgesia was statistically significant $(\mathrm{p} \leq 0.01)$. There was a significant consumption of fentanyl in group $\mathrm{M}$ as compared to group $\mathrm{K}$ where there was no requirement of the rescue analgesia. (Table 1)

The mean difference in consumption of fentanyl within group $\mathrm{M}$ between 0-8 hrs and 8-16 hrs was $16.267 \mu \mathrm{g}$ (p value $=0.003), 8-16 \mathrm{hrs}$ and $16-24 \mathrm{hrs}$ was $30.33 \mu \mathrm{g}(\mathrm{p}$ value $=0.000)$ and $0-8 \mathrm{hrs}$ and 16-24 hrs was $46.600 \mu \mathrm{g} \mathrm{(p}$ value $=0.000)$. On applying the paired t-test, the mean difference of consumption of fentanyl between 0-8 hrs and 8-16 hrs, 8-16 hrs and 16-24 hrs and; 0-8 hrs and 1624 hrs was statistically significant $(\mathrm{p} \leq 0.01)$. The mean difference between $0-8 \mathrm{hrs}$ and $8-16 \mathrm{hrs}$ was less as compared to 8-16 hrs and 16-24 hrs i.e. the consumption was less between 8-16 hrs and 16-24 hrs as compared to 0-8 hrs( Table 2).

At baseline, i. e. at $0 \mathrm{hr}$, the sedation score in both groups was 2 . At $12 \mathrm{hrs}$ and $24 \mathrm{hrs}$, sedation score was 3 in group
$\mathrm{M}$ as compared to 2 in group $\mathrm{K}$ ( $\mathrm{p}$ value $=0.000)$. On applying chi-square test, sedation score was significant in group M. (Table 3)

Deep tendon reflexes and mean serum magnesium levels were calculated in both the groups. On applying unpaired t-test, there was no difference from the baseline in both the groups.

On applying unpaired t test, heart rate and blood pressure were comparable in the two groups. There was no requirement of atropine or ephedrine in any of the groups.

Nausea was present in total 7 patients, 5 in group $\mathrm{M}$ and 2 in group $\mathrm{K}$. On applying chi-square test, the result was insignificant $(\mathrm{p}$ value $=0.228)$. No medication was required. (Table 4 )

Pain is the most common clinical complaint and causes considerable human suffering. It causes marked distress and anxiety and is a major factor that affects recovery of the patient. The International Association for the Study of Pain ( IASP) defines pain as “ an unpleasant sensory and emotional experience which is primarily associated with tissue damage or described in terms of such damage, or both.6 It has been declared as a " fifth vital sign ". Acute pain is defined as pain that is caused by noxious stimulus due to injury and is nearly always nociceptive. Various drugs which are used for pain relief include NSAIDs, opioids and local anaesthetics. There is always a search for newer drugs.

Recently the importance of magnesium in anaesthetic practice has been highlighted. Magnesium is a non competitive N-methyl-D-aspartate (NMDA) receptor antagonist with antinociceptive effects [3]. Some studies have shown a beneficial effect of magnesium on postoperative pain outcomes [7-10]. We were unable to show any apparent beneficial effect of magnesium on pain intensity and analgesic requirements in our study as the literature does not defines the doses of magnesium for pain relief. Also the present study lacked the control group. In the present study the consumption of fentanyl in magnesium group was $168.93 \pm 24.64,152.67 \pm 29.15$, $122.33 \pm 34.23 \mu \mathrm{g}$ while it was nil in ketorolac group at 0-8 hrs, 8-16 hrs, 16-24 hrs respectively. Our results are in agreement with study conducted by Ko et al and Paech et al where perioperative iv magnesium administration did not reduce postoperative pain and analgesic consumption 
Indo Global Journal of Pharmaceutical Sciences, 2015; 5(3): 199-204

in patients undergoing abdominal hysterectomy and caesarean delivery [11-12]. Tramer et al also showed that the pretreatment of magnesium sulphate in patients undergoing ambulatory ilioinguinal hernia repair or varicose vein operations had no effect on postoperative analgesia [13]. Less pain relief in magnesium group in the present study can be attributed to the usage of decreased dose of magnesium as this is the first study of its kind and exact dose of $\mathrm{Mg}$ for acute pain relief is not mentioned in literature. Also, $\mathrm{Mg}$ is not a primary analgesic in itself, it enhances the analgesic actions of more established analgesics as an adjuvant agent [14].

Table 1 Total consumption of rescue analgesia (fentanyl) in group $\mathrm{M}$ and $\mathrm{K}$ at various intervals (mean $\pm \mathrm{SD}$ )

\begin{tabular}{|c|c|c|c|}
\hline \multirow{2}{*}{ Time interval } & $\begin{array}{c}\text { Group M } \\
(\mathbf{n = 3 0}) \\
\end{array}$ & $\begin{array}{c}\text { Group K } \\
(\mathbf{n = 3 0}) \\
\text { Rescue analgesia }(\boldsymbol{\mu g})\end{array}$ & $\begin{array}{c}\text { p value } \\
\text { Rescue analgesia }(\boldsymbol{\mu g})\end{array}$ \\
\hline $0-8 \mathrm{hrs}$ & $168.93 \pm 24.64$ & $0.00 \pm 0.00$ & 0.000 \\
\hline $8-16 \mathrm{hrs}$ & $152.67 \pm 29.15$ & $0.00 \pm 0.00$ & 0.000 \\
\hline $16-24 \mathrm{hrs}$ & $122.33 \pm 34.23$ & $0.00 \pm 0.00$ & 0.000 \\
\hline
\end{tabular}

Table 2 Mean difference in total consumption of rescue analgesia within group $M$

\begin{tabular}{|c|c|c|c|}
\hline \multirow{2}{*}{ Time interval } & Time interval & $\begin{array}{c}\text { Mean difference } \\
\text { In rescue analgesia } \\
(\boldsymbol{\mu g})\end{array}$ & \begin{tabular}{c} 
p value \\
\hline $0-8 \mathrm{hrs}$
\end{tabular} \\
\hline $8-16 \mathrm{hrs}$ & $8-16 \mathrm{hrs}$ & 16.26 & .003 \\
\hline $0-8 \mathrm{hrs}$ & $16-24 \mathrm{hrs}$ & 30.33 & .000 \\
\hline
\end{tabular}

Table 3 Sedation Score

\begin{tabular}{|c|c|c|c|c|}
\hline & Sedation score & $\begin{array}{c}\text { Group M } \\
\text { No of patients }\end{array}$ & $\begin{array}{c}\text { Group K } \\
\text { No of patients }\end{array}$ & p value \\
\hline $0 \mathrm{hr}$ & 2 & 30 & 30 & - \\
\hline \multirow[t]{2}{*}{$12 \mathrm{hrs}$} & 2 & 0 & 30 & \multirow[t]{2}{*}{0.000} \\
\hline & 3 & 30 & 0 & \\
\hline \multirow[t]{2}{*}{$24 \mathrm{hrs}$} & 2 & 0 & 30 & \multirow[t]{2}{*}{0.000} \\
\hline & 3 & 30 & 0 & \\
\hline
\end{tabular}


Indo Global Journal of Pharmaceutical Sciences, 2015; 5(3): 199-204

Table 4 Complications

\begin{tabular}{|c|c|c|c|c|}
\hline \multicolumn{2}{|l|}{ Complications } & \multirow{2}{*}{$\begin{array}{c}\text { Group M } \\
\text { No \of } \\
\text { patients } \\
0\end{array}$} & \multirow{2}{*}{$\begin{array}{c}\text { Group K } \\
\text { No of patients } \\
0\end{array}$} & \multirow{2}{*}{$\begin{array}{c}\text { p value } \\
-\end{array}$} \\
\hline \multirow[t]{2}{*}{ Dizziness } & Yes & & & \\
\hline & No & 30 & 30 & \\
\hline \multirow[t]{2}{*}{ Nausea/Vomiting } & Yes & 5 & 2 & \multirow[t]{2}{*}{0.228} \\
\hline & No & 25 & 28 & \\
\hline \multirow[t]{2}{*}{ Vomiting } & Yes & 0 & 0 & \\
\hline & No & 30 & 30 & \\
\hline \multirow[t]{2}{*}{ Bradycardia/Hypotension } & Yes & 0 & 0 & \multirow[t]{2}{*}{-} \\
\hline & No & 30 & 30 & \\
\hline \multirow[t]{2}{*}{ Hyporeflexia } & Yes & 0 & 0 & \multirow[t]{2}{*}{-} \\
\hline & No & 30 & 30 & \\
\hline \multirow[t]{2}{*}{ Any other } & Yes & 0 & 0 & \multirow[t]{2}{*}{-} \\
\hline & No & 30 & 30 & \\
\hline
\end{tabular}

The normal range of magnesium in plasma is 1.4-2.2 $\mathrm{meq} / \mathrm{L}$. Hypomagnesimia can occur frequently after surgeries such as abdominal, orthopaedic and cardiac surgery as well as after minor surgeries $[\mathbf{9 , 1 4}]$. Tramer et al hypothesized that magnesium substitution was beneficial as an analgesic only in patients who had hypomagnesimia [13]. Thus decrease in pain intensity was not due to a direct analgesic effect of magnesium but rather to the prevention of hypomagnesemia and thus prevention of subsequent NMDA activation. Patients undergoing major surgery without magnesium supplementation were shown to be at risk of developing hypomagnesimia in the first 24 postoperative hours [15]. Ths decrease was probably due to the large loss of fluids and fluid movement between body compartments. Magnesium is a non competitive blocker of NMDA receptor. It was observed that in magnesium free solutions, the excitatory amino acids L-glutamate and Laspartate opened the NMDA cation channels and in the presence of magnesium, the probability of opening of the channel was reduced.16 Thus, substitution of Magnesium in surgical patients at risk of developing hypomagnesimia should prevent hypomagnesimia related opening of the NMDA receptors. We estimated $\mathrm{Mg}$ levels before the start of the study and these were normal in our patients.
Though rescue analgesia required was more in magnesium group, however, when the total consumption of rescue analgesia within group $\mathrm{M}$ was analysed and compared at different intervals, our study showed that magnesium decreased the analgesic consumption of fentanyl (from $168.93 \pm 24.64 \mu \mathrm{g}$ to $152.67 \pm 29.15 \mu \mathrm{g}$ to $122.33 \pm 34.23 \mu \mathrm{g}$ ) with every passing hour.

No major side effects were seen in the present study. Seven patients, five in magnesium group and two in ketorolac group complained of nausea, which was selflimiting and recovered spontaneously within $30 \mathrm{~min}$ without any medication. Though Magnesium may induce hypotension by vasodilatation, sympathetic blockade and inhibition of catecholamine release, but we did not observe any hypotensive episodes. Significant hypotension has been reported by some authors [17].

Patients of $\mathrm{Mg}$ group were more sedated compared to ketorolac group. The mechanism for this sedation may be due to CNS depression by $\mathrm{MgSO} 4$ [18]. In addition, these patients required fentanyl as rescue analgesia.

We also evaluated the serum magnesium levels at the start of study and, after $24 \mathrm{hrs}$, at the end of the study. The levels in both groups were within normal limits at both 


\section{Indo Global Journal of Pharmaceutical Sciences, 2015; 5(3): 199-204}

the occasions. There was no increase in levels after 24 hrs. The average serum magnesium levels in group $\mathrm{M}$ was 0.83 mmolL- 1 at the end of the study.

Even after extensive search in the available literature, the present results could not be completely compared to others, as all previous studies done were during the intraoperative and post-operative periods, and none of them evaluated the effects pre-operatively in an acute trauma condition. However, we found a reduction in the fentanyl consumption within the magnesium group at different time intervals which decreased with every passing hour. Our study is the first randomized study, wherein IV magnesium has been used as an analgesic agent in acute trauma patients.

The limitation of this study is that we had used a fixed dose of magnesium. Instead, a dose according to individual's weight could have been more appropriate. Secondly, a comparison between two different doses of magnesium would probably be needed to evaluate the effects of two different doses in addition to comparison of $\mathrm{Mg}$ to control group. Therefore, further studies are required to evaluate an effective dose of magnesium for analgesia.

\section{REFERENCES}

[1] Litvak KM, McEvoy GK AHFS. Ketorolac, an injectable non- narcotic analgesic. Clinical Pharmacy 1990; 9(12): 921-35.

[2] Burke A, Smyth E, FitzGerald GA. In: Analgesic-antipyretic agents; Pharmacotherapy of gout. In : Brunton LL, Lazo JS, Parker KL, eds. Goodman and Gilman's The Pharmacological Basics of Therapeutics. 11th ed. London. McGraw Hill; 2006.p.671-715.

[3] Telci L, Esen F, Akcoral D, Erden T, Canbolat AT, Akpir K. Evaluation of effects of magnesium sulphate in reducing intraoperative anaesthetic requirements. Br J Anaesth 2002; 89: 594-8.

[4] Macintyre PE. Safety and efficacy of patient controlled analgesia. Br J anaesth 201;87: 36-46.
[5] Ramsay M, Savege T, Simpson BRJ. Controlled sedation with alphaxalone/alphadolone. BMJ 1974; 2: 656-9.

[6] IASP Sub-committee on Taxonomy. Pain terms: a list with definitions and notes on usage. Pain 1980; 8: 249-52.

[7] Ryu JH, Kang MH, Park KS, Do SH. Effects of magnesium sulphate on intraoperative anaesthetic requirements and postoperative analgesia in gynaecology patients receiving total intravenous anaesthesia. Br J Anaesth 2008; 100: 397-403.

[8] Lee C, Jang MS, Song YK, Seri O, Moon SY, Kang DB et al. The effect of magnesium sulphate on postoperative pain in patients undergoing major abdominal surgery under remifentanil-based anaesthesia. Korean J Anesthesiol 2008; 55: 286-90.

[9] Koinig H, Wallner T, Marhofer P, Andel H, Horauf K, Mayer N. Magnesium sulphate reduces intra and postoperative analgesic requirements. Anesth Analg 1998; 87: 206-10.

[10] Kara H, Sachin N, Ulusan V, Aydogdu T. Magnesium infusion reduces perioperative pain. Eur J Anaesthesiol 2002; 19 (1): 52-6.

[11] Ko SH, Lim HR, Kim DC, Han YJ, Choe H, Song HS. Magnesium sulphate does not reduce postoperative analgesic requirements. Anesthesiology 2001; 95: 640-6.

[12] Paech MJ, Magann EF, Doherty DA, Verity LJ, Newnham JP. Does magnesium sulphate reduce the short and long term requirements for pain relief after caesarean delivery? A double-blind placebocontrolled trial. Am J Obstet Gynecol 2006; 194: 1596-602.

[13] Tramer MR, Glynn CJ. An evaluation of a single dose of magnesium to supplement analgesia after ambulatory surgery: randomized controlled trial. Anesth Analg 2007; 104: 1374-9.

[14] Do SH. Magnesium: a versatile drug for anaesthesiologists. Korean J Anesthesiol 2013; 65: 4-8.

[15] Sanchez-Capuchino A, McConachie I. Perioperative effect of major gastrointestinal surgery on serum magnesium. Anaesthesia 1994; 49: 912-4.

[16] Nowak L, Bregestovski P, Ascher P, Herbet A, Prochiantz A. Magnesium gates glutamate-activated channels in mouse central neurones. Nature 1984; 307: 462-5.

[17] Elsharnouby NM, Elsharnouby MM. Magnesium sulphate as a technique of hypotensive anaesthesia. Br J Anaesth 2006; 96: 72731.

[18] Kiran S, Gupta R, Verma D. Evaluation of a single-dose of intravenous magnesium sulphate for prevention of postoperative pain after inguinal surgery. Indian J Anaesth 2011; 55: 31-5.

Indo Global Journal of Pharmaceutical Sciences( ISSN 22491023 ; CODEN- IGJPAI; NLM ID: 101610675) indexed and abstracted in EMBASE(Elsevier), SCIRUS(Elsevier),CABI, CAB Abstracts, Chemical Abstract Services(CAS), American Chemical Society(ACS), Index Copernicus, EBSCO, DOAJ, Google Scholar and many more. For further details, visit 